\title{
IFNA2 Gene
}

National Cancer Institute

\section{Source}

National Cancer Institute. IFNA2 Gene. NCI Thesaurus. Code C24482.

This gene plays a role in signal transduction, the immune response and positive regulation of apoptosis. 